\title{
EUROPEAN SMALL CLAIMS PROCEDURE AND ITS PLACE IN THE SYSTEM OF POLISH SEPARATE PROCEEDINGS
}

\author{
Joanna May \\ Ph.D., Assistant Professor at the Chair of Law and Civil \\ Proceedings of Nicolaus Copernicus University in Toruń, \\ legal counsel (radca prawny) of Warsaw \\ RCLC ORCID 0000-0001-8660-0784 \\ (Torun, Poland) \\ Małgorzata Malczyk \\ Ph.D., Assistant Professor at the Chair of Civil \\ Proceedings of Jagellonian University, solicitor \\ of Cracow S.C. ORCID 0000-0001-5625-979X \\ (Krakow, Poland)
}

https://doi.org/10.33327/AJEE-18-2.3-a000012

Summary: - 1. Introduction. - 2. The Notion and Types of Separate Proceedings and Their Place in Court Civil Proceedings. - 3. Criteria for Distinguishing Separate Proceedings. - 4. European Small Claims Procedure as Separate Proceedings. General Issues. - 5. Relationship Between the European Small Claims Procedure and Other Separate Proceedings. - 5.1. Order for Payment Proceedings. - 5.2. Writ of Payment Proceedings. - 5.3. Electronic Writ of Payment Proceedings. - 5.4. Simplified Procedure. - 5.5. European Order for Payment Procedure. - 6. Concluding Remarks.

The European proceedings in cross-border cases, to which the European order for payment and the European Small Claims Procedures belong, were introduced into Polish legal system on 12 December 2008 as an alternative to the existing proceedings provided for in the laws of the Member States. The base for the application of the European Small Claims Procedure is Regulation (EC) No 861/2007 of the European Parliament and of the Council of 11 July 2007, establishing the European Small Claims Procedure.

The Polish legislator decided to place a modest regulation of these procedures amongst separate proceedings. To approximate the subject issue, the nature of the European Small Claims Procedure needs to be considered along with its relations with selected separate proceedings (such as order for payment proceedings, writ of payment proceedings, electronic writ of payment proceedings, simplified procedure and European order for payment 
procedure), the nature of which justifies including them in the group of accelerated and simplified proceedings.

Keywords: European Proceedings in Cross-border Cases, European Small Claims Procedure, Separate Proceedings, Accelerated Proceedings, Simplified Proceedings, Crossborder Cases.

\section{INTRODUCTION}

The European proceedings in cross-border cases, to which the European Order for Payment (hereinafter - EOP) and the European Small Claims Procedures (hereinafter - ESCP) belong, were introduced into Polish legal system on 12 December 2008 as an alternative to the existing proceedings provided for in Poland. The bases for the application of these proceedings are: in the case of the European order for payment, the provisions of Regulation (EC) No 1896/2006 of the European Parliament and of the Council of 12 December, 2006, establishing the European order for payment procedure; and for European Small Claims Procedure - Regulation (EC) No 861/2007 of the European Parliament and of the Council of 11 July 2007, establishing the European Small Claims Procedure.

The court examines the case in the European Order Procedure or the European Small Claims Procedure if the conditions are met accordingly as set out in the provisions of Regulation No. 1896/2006 (Art. 505 ${ }^{15} \$ 1$ of the Code of Civil Proceedings, hereinafter the CCP) or Regulation 861/2007 (Art. $505^{21} \$ 1$ of the CCP), and the common feature of these proceedings is the cross-border nature of the case, which is the basis for the decision.

The Polish legislator decided to place a modest regulation of these procedures amongst separate proceedings. ${ }^{1}$ To approximate the subject issue, the nature of the European Small Claims Procedure needs to be considered along with its relations with other separate proceedings.

\section{THE NOTION AND TYPES OF SEPARATE PROCEEDINGS AND THEIR PLACE IN COURT CIVIL PROCEEDINGS}

The fact-finding proceedings have an essential position in court civil proceedings. Their purpose is to examine and resolve a civil case within the meaning of Art. 1 of the CCP. The fact-finding proceedings are divided into two modes: civil litigation and nonlitigious proceedings. The model civil procedure mode includes in its scope ordinary proceedings (also referred to as proceedings on general principles) and separate proceedings (Art. $13 \$ 1$ of the CCP). ${ }^{2}$

According to the assumptions of the legislator, the ordinary proceedings are those foreseen for the majority of civil cases. However, the successive increase in the number

1 These proceedings are optional in national cases, cf. $€$ Goździaszek, 'Europejskie postępowanie w sprawach drobnych roszczeń' (2009) No 9 Monitor Prawniczy 471.

2 Cf. M Manowska, Postępowania odrębne $w$ procesie cywilnym (LexisNexis 2010) 11 and subs.; M Miszewski, Proces cywilny w zarysie. Część pierwsza (Księgarnia Wydawnictw Prawniczych i Naukowych 1946) 245. 
of separate proceedings had such a consequence that proportionally to the increase in the number of cases heard in separate proceedings, their significance also grew. ${ }^{3}$

The legislator repeatedly uses the notions of proceedings or separate proceedings in the Code of Civil Proceedings, but fails to introduce their legal definition, whereby in the study of civil procedural law, it can be noticed that the understanding of these notions is not uniform. ${ }^{4}$ Separate proceedings are referred to as a special procedure ${ }^{5}$ or special litigious proceedings, ${ }^{6}$ extraordinary proceedings, ${ }^{7}$ or a special type of ordinary proceedings. $^{8}$

Separate proceedings are regulated in the Code of Civil Proceedings in Title VII of the first book (Litigation), placed in the first part (Fact-finding proceedings). Title VII, consisting of thirteen sections, includes provisions from Art. 425 to Art. $505^{39}$ of the CCP. However, this does not mean that there are thirteen separate proceedings, though it needs admitting that the system of the code has a certain impact on the identification of separate proceedings.

The classification of these proceedings is differently presented in the jurisprudence, which undoubtedly affects their number, nevertheless, the Code of Civil Proceedings indicates the following separate proceedings: ${ }^{9}$

1) Proceedings in Matrimonial Cases (Art. 425 - 452 of the CCP);

2) Proceedings in Cases Involving Parent-Child Relationship (Art. 453 - 458 of the CCP);

3) Proceedings in Labour Law Cases (Art. 459 - 476 and Art. $477-477^{7}$ of the CCP);

4) Proceedings in Social Insurance Cases (Articles 459-476 and Art. $477^{8}-477^{14 a}$ of the CCP);

5) Proceedings in Cases Involving Infringement of Possession (Articles 478 - 479 of the CCP);

6) Proceedings in Cases Involving Competition and Consumer Protection, and on Practices Unfairly Using a Contractual Advantage (Art. $479^{28}-479^{35}$ of the CCP);

7) Proceedings in Cases Pertaining to Energy Regulations (Articles $479^{46}-479^{56}$ of the CCP);

3 W Broniewicz indicates that the proportions of cases examined in ordinary proceedings and in separate proceedings have been reversed, cf. W Broniewicz (updated by I Kunicki) in W Broniewicz, A Marciniak, I Kunicki (eds) Postępowanie cywilne w zarysie (Wolters Kluwer Polska 2016) 352.

4 More on differentiated understanding of the notion of 'separate proceedings' M Osowska-Grzelak, 'Wzajemna relacja postępowań odrębnych występujących w procesie cywilnym w ujęciu ogólnym - p. I', (2008) 13 Monitor Prawniczy 694 and subs, along with the literature cited there.

5 Cf. J Gudowski in T Ereciński (ed), Kodeks postępowania cywilnego. Komentarz. Część pierwsza. Postepowanie rozpoznawcze. (Commentary. First Part. Fact-finding procedure), (Vol I, Lexis Nexis 2012) 175 , who is of the opinion that separate proceedings make up a particular type of process, proper in cases, separated by the legislator - according to their features - from amongst all cases examined in the litigation. Cf. Miszewski (n 2) 149. T Ereciński aptly draws attention to the necessity to use the word 'Mode' only with reference to the civil litigation and non-litigious proceedings, cf. T Ereciński, 'Postępowania odrębne de lege lata i de lege ferenda' in H Dolecki, K Flaga- Gieruszyńska (eds), Ewolucja polskiego postępowania cywilnego wobec przemian politycznych, społecznych i gospodarczych, Materiały konferencyjne Ogólnopolskiego Zjazdu Katedr Postępowania Cywilnego, Szczecin-Niechorze 2830.9.2007 (Conference materials of All-Poland Congress of the Chairs of Civil Proceedings, SzczecinNiechorze 28-30.9.2007, CH Beck 2009) 1.

6 J Jodłowski (updated by J Lapierre, and then by K Weitz) in J Jodłowski, Z Resich, M Lapierre, M MisiukJodłowska, K Weitz, Postępowanie cywilne (LexisNexis 2007) 41, who distinguishes (litigious) general proceedings and special litigations.

7 To distinguish from ordinary proceedings, or another ordinary litigation, cf. W Siedlecki in J Jodłowski, W Siedlecki, Postępowanie cywilne. Część ogólna (PWN 1958) 34.

8 Osowska-Grzelak (n 4) 700.

9 It is worthy of mentioning that the legislator plans to restore proceedings in commercial cases, although in a changed shape in its 25 October 2018 draft of the CCP. 
8) Proceedings in Cases Pertaining to Telecommunication and Postal Regulations (Art. $479^{57}-479^{67}$ of the CCP);

9) Proceedings in Cases Pertaining to Railway Transport Regulations (Art. $479^{68}-479^{78}$ of the CCP);

10) Proceedings in Cases Pertaining to Water and Sewage Market Regulation (Art. $479^{79}$ $479^{88}$ of the CCP);

11) Order for Payment Proceedings (Art. $484^{1}-497$ of the CCP);

12) Writ of Payment Proceedings (Art. $497^{1}-505$ of the CCP);

13) Simplified Procedure (Art. $505^{1}-505^{14}$ of the CCP);

14) European Order for Payment Procedure (Articles $505^{15}-505^{20}$ the CCP);

15) European Small Claims Procedure (Art. $505^{21}-505^{27 a}$ of the CCP);

16) Electronic Writ of Payment Proceedings (Art. $505^{28}-505^{38}$ the CCP).

The system of the code itself allows to group separate proceedings, given certain common features, for instance, the legislator dealt in one section with proceedings in labour and social insurance law, order for payment and writ of payment proceedings or European procedure in cross-border cases. Depending on the adopted convention, it may be acknowledged that there are three separate proceedings, ${ }^{10}$ following the system of the Code of Civil Proceedings, or else that each of these proceedings constitutes a separate procedure. ${ }^{11}$ The jurisprudence also presents intermediate positions, which recognize the proceedings in labour law and social insurance cases as a single procedure, but the order for payment proceedings and the writ for payment proceedings as two separate ones. ${ }^{12}$

Dealing with the so-called regulatory proceedings is different from the point of view of Polish procedural law system, i.e. Proceedings in Cases Pertaining to Energy Regulations, Proceedings in Cases Pertaining to Telecommunication and Postal Regulations, Proceedings in Cases Pertaining to Railway Transport Regulations and Proceedings in Cases Pertaining to Water and Sewage Market Regulation. Each of them is dealt with in a separate section, although their essence and legal character would allow to find many common features. ${ }^{13}$

In turn, in the section devoted to proceedings in matrimonial cases, the legislator separates individual chapters to emphasize the differences between proceedings in cases of divorce and separation (Art. 425 - 435 and Art. 436 - 446 of the CCP) and other matrimonial cases (Art. 425 - 435 and Art. 447 - 452 of the CCP).${ }^{14}$ In this respect, opinions diverge also in the literature of the subject, whether we deal with one or two separate proceedings.

In the classification of separate proceedings, the understanding of matrimonial cases proceedings as one separate procedure dominates. ${ }^{15}$

The notion of separate proceedings shall be understood as proceedings different from their ordinary type, placed in the Code of Civil Proceedings in its first book of the first part, which confirms that separate proceedings are positioned within litigious

10 J Bodio in A Jakubecki (ed) Kodeks postępowania cywilnego. Praktyczny komentarz (Zakamycze 2005$) 52$.

11 Thus Gudowski (n 5) 175; Osowska-Grzelak (n 4) 694 and subs.

12 Thus Manowska (n 3) 16.

13 In the jurisprudence, the so-called regulatory proceedings had been included into commercial cases proceedings, before the laws dealing with them were cancelled cf. Osowska-Grzelak (n 5) 695 and subs.

14 cf. Broniewicz (n 4) 352 and subs.

15 Thus Manowska (n 2) 16; J Bodio (n 10) 52; Gudowski (n 5) 175. 
procedure of cases examination. ${ }^{16}$ Separate proceedings are either summarized and simplified proceedings or those differently regulated in consequence of special features of cases being their subject ${ }^{17}$. Each time, the presiding judge examines, already at the initial stage of the proceedings, the mode in which the case shall be examined and, when its hearing shall take place in the civil litigation, whether it shall be in accordance with the provisions on separate proceedings (Art. $201 \$ 1$ of the CCP). The specificity of these proceedings, which is the basis for their separation, means that the court, when examining a case eligible for specific separate proceedings, first applies the provisions of a given procedure, and only in the absence of a different regulation, it will apply not contradictory, general provisions, regulating ordinary proceedings. ${ }^{18}$

\section{CRITERIA FOR DISTINGUISHING SEPARATE PROCEEDINGS}

In the literature on the subject, two basic criteria decisive what belongs to the given separate proceedings are indicated, namely the need to speed up and simplify the proceedings or the need to differentiate the cases due to the special properties that are their object. ${ }^{19}$

The first of these criteria, i.e. the need to speed up and simplify the proceedings, encouraged the legislator to establish the order for payment, the writ of payment, the simplified or electronic writ of payment proceedings, although this assumption is also evident, to some extent, in the norms of the proceedings in cases involving infringement of possession. ${ }^{20}$

Originally, in the order for payment and the writ of payment proceedings, and later also in the electronic writ of payment proceedings, ${ }^{21}$ relatively simple cases were to be examined. The order for payment was issued at a closed session on the basis of factual circumstances invoked by the claimant in the lawsuit (thus, in the electronic writ of payment proceedings, as well as, in the writ of payment proceedings) and on the basis of documents attached thereto, (thus, in the order for payment procedure).

As the name already suggests, simplified proceedings, although the case is to be heard at the oral hearing, contain in the norms, regulating this procedure, a series of simplifications that have a major impact on their faster course. They concern, among other things, the obligation to file the lawsuit on an official form (Art. $505^{2}$ of the CCP), the prohibition of claims cumulating and fragmentizing (Art. $505^{3}$ of the CCP), the prohibition of changing the claim's subject and object (Art. $505^{4} \$ 1$ of the CCP), the right to renounce the justification being served, as well as, the right to appeal (Art. $505^{8}$ $\$ 2$ and 3 of the CCP).

16 Manowska (n 2) 11; cf. also M Manowska, Postępowanie nakazowe i upominawcze (C.H. Beck 2001) 9 and subs.

17 W Siedlecki, Postępowanie cywilne. Zarys wykładu (PWN 1977) 16.

18 Cf. Gudowski (n 5) 176.

19 T Ereciński also indicates one essential criterion, and namely, the nature of the case, widely understood, both as 'objective' (resulting from a set out right or substantive law relationship) or 'simple' or else 'small', cf. Ereciński (n 5) 1 i 10.

20 This occurs because of the narrow scope of cognizance in these proceedings, limited to the fact of last possession and its infringement, independently of the property rights, cf. Ereciński (n 6) 8.

21 The electronic writ of payment proceedings were introduced by the 9 January 2009 Law on amendments to the Code of Civil Proceedings and Some Other Laws (J. of L. No 26, item 156) which came into force on 1 January 2010. 
The European procedure in cross-border cases, some of the solutions characteristic for these proceedings taken into account, also allow to include them in the group of sped up and simplified proceedings, which is proved at least by the use of official forms or substantive consideration of the case in camera.

It is also worth underlining that some of the proceedings which make part of the socalled sped up proceedings feature an optional nature. The most expressive regulation related thereto is contained in Art. $484^{1} \$ 2$ of the CCP, according to which the court resolves the case in the order for payment proceedings upon the claimant's written request filed in the lawsuit.

In turn, in cross-border proceedings, this optional character is manifested in the claimant's will when they file the lawsuit on a special form, whereas in electronic writ of payment proceedings - when filing the lawsuit by means of the ICT system.

The writ of payment proceedings do not match this classification, because it is the presiding judge who decides that the writ of payment proceedings shall be applied to the case (Art. $201 \$ 1$ of the CCP). The same applies to other separate proceedings, in which the classification of a case to particular proceedings is obligatory.

In the first place, simplified proceedings shall be mentioned in this group, which although summarized, have an obligatory character. An interesting solution in these proceedings are the rules that provide for an exception - cognizing a case, falling within the scope of simplified proceedings (Art. $505^{1}$ of the CCP), without applying the provisions of this procedure, if the case is particularly complex or its resolution requires special knowledge (Art. $505^{7}$ of the CCP). This is a unique legal norm that allows to switch from separate proceedings of an obligatory nature to ordinary proceedings. Since, as a rule, cognizance of cases eligible for separate proceedings is of exclusive character, it means that these cases cannot be examined in ordinary proceedings (absolute exclusivity). This rule has an exception, precisely in the abovementioned simplified proceedings (Art. $505^{7}$ of the CCP), in the writ of payment proceedings and the electronic writ of payment proceedings. In the latter two proceedings, effective filing of opposition against an order for payment may lead to the referral to ordinary proceedings, unless the case is eligible for simplified proceedings (Art. $505^{1}$ of the CCP), which suggests that separate proceedings can overlap (cross). ${ }^{22}$

The remaining separate proceedings have obligatory nature because of the specificity of cases recognized in them. In this case, the absolute exclusivity occurs, so these cases can be under examination only in specific separate proceedings for which a given case is eligible.

Most of these proceedings coincide with the second criterion of distinction mentioned above, which relates to the different regulation of cases (privileged) in consequence of their special features (object or subject privilege) ${ }^{23}$ These cases are based on the criterion

22 Overlapping or else crossing of these separate proceedings with each other can occur in the case of pecuniary claims, which means that although the case is eligible for simplified proceedings or labour law cases proceedings, it may be referred by the presiding judge to a camera session so as to render a writ of payment (Art. $201 \$ 1$ sentence 2 of the CCP), the claimant can also lodge an application for issuing an order of payment or sue in electronic writ of payment (when the premises of Art. 485 of the CCP are met), cf. J Lapierre (updated by K Weitz) in J Jodłowski, Z Resich, J Lapierre, M MisiukJodłowska, K Weitz, Postępowanie cywilne (LexisNexis 2007) 372.

23 Cf. A Zieliński, 'Uprzywilejowanie niektórych rodzajów roszczeń w postępowaniu cywilnym' in M Jędrzejewska, T Ereciński (eds), Studia z prawa postępowania cywilnego. Księga pamiątkowa ku czci Zbigniewa Resicha (PWN 1985) 310 oraz 312 and subs.; Ereciński (n 5) 8 and subs. 
of substantive law character and a particular public interest in cognizing them. ${ }^{24}$ The introduction of proceedings in matrimonial cases or proceedings in cases of parents-and-children relations resulted therefore from the nature of the right or legal relationship under protection. The legislator was also guided by this criterion when creating subsequent separate proceedings, such as for cases related to labour law and social insurance or for specific cases, in terms of their object, the so-called regulatory proceedings. It is also noteworthy that some of these proceedings concern civil cases in substantial meaning (such as, proceedings in matrimonial cases or in cases involving parent-child relationship, proceedings in labour law cases), and some cover civil cases in a formal meaning (proceedings in social insurance cases, and the so-called regulatory proceedings).

As aptly noted by T. Ereciński, separate proceedings are not homogenous in consequence of the fact that some of them constitute only an initial phase of procedural proceedings, while others are a separate manner of proceedings, similar to the general process. ${ }^{25}$

\section{EUROPEAN SMALL CLAIMS PROCEDURE AS SEPARATE PROCEEDINGS - GENERAL ISSUES}

The European small claims procedure was introduced to the Polish Code of Civil Proceedings by the amendment which entered into force on $12^{\text {th }}$ December $2008 .^{26}$ The provisions dealing with these proceedings (Art. $505^{21}-505^{27}$ of the CCP) make up the domestic supplement to the provisions contained in the Regulation of the European Parliament and of the Council (EC) No. 861/2007 of 11 July 2007 which established the European Small Claims Procedure, ${ }^{27}$ which were amended later by the Regulation of the European Parliament and of the Council (EU) 2015/242128 of 16 December 2015. The provisions contained in the Regulation No. 861/2007 make up the legal basis for the Polish Court to act in the small claims procedure, whereby pursuant to the provisions of Art. 19 of this Regulation, the European Small Claims Procedure is subject to the procedural provisions of the Member States in which the proceedings take place. In consequence, the provisions of the Polish Code of Civil Proceedings in the small claims procedure deal exclusively with such issues which are not dealt with in Regulation No. 861/2007, nor do they modify or copy the European Union's provisions. They constitute supplementing provisions to the Regulation No. 861/2007, based on domestic law..$^{29}$ In the European Small Claims Procedure before Polish courts, we deal with parallel applications of the provisions of the Regulation No. 861/2007

24 Ereciński (n 5) 9.

25 Ereciński (n 5) 11.

26 Act on amendment - to the Code of Civil Proceedings and some other laws of 5 December 2008, Journal of Laws No. 234, item 1571.

27 Official Journal of the European Union L 199 of 31 July 2007, p. 1, hereinafter referred to as the Regulation No. 861/2007.

28 Official Journal of the European Union L 341 of 24 December 2015, p. 1, hereinafter referred to as the Regulation No. 2015/2421. This Regulation also amended the Regulation (EC) No. 1896/2006, which established proceedings with regard to the European order for payment.

29 A Harast-Sidorowska, 'Commentary to Art. $505^{21}$ the CCP' in A Góra-Błaszczykowska (ed), Code of Civil Proceedings, Vol. I, Commentary to Art. 1-729 (C.H. Beck 2016) 1528-1529. 
and the provisions of the Code of Civil Proceedings, which supplement the provisions of the above-mentioned regulation.

Pursuant to point 8, first sentence, of the recitals of the Regulation No. 861/2007, the purpose of these proceedings is to simplify and speed up the course of disputed proceedings related to small claims in cross-border cases, and also to reduce the costs by making available an optional tool, supplementing the procedures existing in the individual Member States law, which remains intact.

The European Small Claims Procedure is an optional, separate procedure, which is autonomous with regard to the other separate Polish proceedings, as pursuant to Art. $505^{21} \S 2$ of the CCP, the CCP provisions on other separate proceedings are not applied in cases examined according to the provisions of the European Small Claims Procedure.

The Regulation No. 861/2007 is eligible in cross-border cases of a civil and commercial nature, notwithstanding the type of court and tribunal, in the case, when the value of the disputed claim, with the exclusion of all the interest, expenses and disbursements does not exceed EUR 5,000 at the moment when the application form is submitted to the competent court or tribunal. The Regulation is not applied in particular to revenue, customs or administrative cases, nor to those related to the State's liability for acts or omissions in the exercise of State authority ('acta iure imperii'), those related to civil status, legal capacity and capacity for legal deeds of natural persons, property relationships, arising from matrimony or a union recognised based on the provisions which are to be applied to such a union as having comparable effects to the consequences of marriage, maintenance duties, arising from a family relationship, relationship of marriage, kinship or affinity, last wills and succession, including maintenance duties, occurring as a result of death, bankruptcy, arrangement or any other similar proceedings, social security, conciliatory tribunals, labour law, lease or tenancy of real estate, with the exclusion of claims related to pecuniary claims or breach of privacy and personal goods, including defamation (Art. 2).

For the purposes of this Regulation, a cross-border case is understood as one in which at least one Party has the place of residence or habitual stay in a Member State other than the Member State of the court or tribunal which examines the case and the moment proper to decide whether a given case is of a cross-border nature is the day when the application was submitted to the competent court or tribunal (Art. 3 subpara. 1 and 3).

The issue of European Small Claims Procedure's relation to the other separate proceedings is dealt with in Polish procedural law.

\section{RELATION BETWEEN THE EUROPEAN SMALL CLAIMS PROCEDURE AND OTHER SEPARATE PROCEEDINGS}

\subsection{ORDER FOR PAYMENT PROCEEDINGS}

It is necessary to determine the type of cases that can theoretically be examined in both separate proceedings, with reference to Art. 485 of the CCP and to Art. 2 and 3 of the Regulation No. 861/2007 in conjunction with Art. $505^{21} \S 1$ of the CCP. These are civil and commercial cases of a cross-border nature, if the circumstances to justify the 
request are proved by documents indicated in Art. 485 of the CCP, ${ }^{30}$ and the value of the cause of action, with the exclusion of interest, expenses and disbursements, does not exceed the equivalent of Euro 5,000 at the moment the action comes to the court, and in addition, these cases are not listed in Art. 2 subpara. 1 sentence 2 and subpara. 2 of the Regulation cited.

The relationship between these separate proceedings shall be examined, their optional nature taken into account, which means that it is the claimant who decides in which of these proceedings they will assert their claim (the claimant has the choice: either the order for payment or the European Small Claims Procedure). The claimant's choice of one of the above-mentioned separate proceedings has it that during the proceedings initiated, the simultaneous or supplementary application of the rules of the other proceedings is not allowed. This issue is dealt with in Art. $505^{21} \$ 2$ of the CCP, according to which in the case examined under the rules of the European Small Claims Procedure, no provisions of any other separate proceedings can be applied. ${ }^{31}$

Pursuant to Article $505^{27} \$ 2$ of the CCP, by reversing the judgment appealed against, the second instance court transfers the case to be re-examined, the rules of separate proceedings being excluded. The above rule leads to the conclusion that after the case is resolved by the court of first instance in the European Small Claims Procedure and the judgment is reversed by the second instance court, the subsequent application of the rules of order for payment proceedings is unacceptable.

$30 \quad$ Art. $485 \$ 1$ of the CCP. The Court issues an order for payment if the claimant pursues a claim for money or for the performance of other replaceable things and the circumstances which justify the claim being pursued are proved by the following documents attached to the statement of claim:

1) an official document;

2) a bill approved by the debtor;

3) summons for the debtor to pay and a written declaration by the debtor on acknowledgement of the debt;

4) a demand for payment accepted by the debtor, returned by the bank and unpaid because of lack of resources on the bank account.

$\$ 2$. The Court also issues an order for payment against a person obligated from a promissory note, a cheque, a warrant or a bill of debt, properly filled in, whose correctness and content raise no doubt. In the case the rights from the promissory note, cheque, warrant or bill of debt have passed to the claimant, so as to issue the order, it is necessary to present documents to justify the claim, and if the passage of these rights onto the claimant does not result directly from the promissory note, cheque, warrant or bill of debt.

$\S 2 \mathrm{a}$. The Court issues an order for payment based on the contract, the proof of having fulfilled the mutual non-pecuniary performance, the proof of having served the invoice or bill on the debtor if the claimant pursues claims related to payment of pecuniary performance, interest in commercial transactions set out in the 8 March 2013 Law on Deadlines for Payments in Commercial Transactions (Journal of Laws of 2016, item 684 and of 2018, item 650), or an amount set out in Art. 10 subpara. 1 of this Law and pursuant to documents which confirm having borne the costs of the receivables collected if the claimant also pursues the costs set out in Art. 10 subpara. 2 of this Law.

$\S 3$. The Court may issue an order for payment if the bank pursues the claim based on an extract from a bank account books, signed by the persons authorised to make declarations in the scope of material rights and obligations of the bank, and stamped with the bank's seal, as well as a proof that the debtor has been served the demand for payment.

$\$ 4$. If the original of the promissory note, cheque, warrant or bill of debt or of the document set out in $\$ 3$ has not been attached, the presiding judge summons the claimant to submit them under pain of the return of claims, based on Art. 130 .

31 Compare, more on this subject: S Cieślak, 'System postępowań przyspieszonych w procesie cywilnym po zmianach Kodeksu postępowania cywilnego wprowadzanych w życie w latach 2008-2010' in J Gudowski, K Weitz (eds), Aurea praxis, aurea theoria: księga pamiątkowa ku czci Profesora Tadeusza Erecińskiego, (Vol 1, Lexis Nexis 2011) 87-107. 


\subsection{WRIT OF PAYMENT PROCEEDINGS}

Undoubtedly, there are cases that can be hypothetically examined both in the European Small Claims Procedure and in the writ of payment proceedings. These are civil and commercial cases of a cross-border nature in which only pecuniary claims are pursued (Article $498 \$ 1$ of the $\mathrm{CCP}^{32}$ ), provided that the value of the cause of action, interest, expenses and disbursements excluded, does not exceed the equivalent of EUR 5,000 at the moment the claim form comes to the court, and in addition, these cases are not listed in Art. 2 subpara. 1 sentence 2 and subpara. 2 of the Regulation No. 861/2007.

If the claimant chooses for their claim the optional European Small Claims Procedure, then, pursuant to Art. $505^{21} \$ 2$ of the CCP, the simultaneous and supplementary application of the rules of writ of payment proceedings is unacceptable in this procedure. It shall be also assumed that the subsequent referral of such a case to the writ of payment proceedings, being a separate, mandatory procedure, was excluded by the Polish legislator, because by reversing the judgment appealed against, the court of second instance transfers the case to be re-examined, the rules on separate proceedings excluded (Article $505^{27} \$ 2$ of the CCP).

In the case, the claim is pursued in the writ of payment proceedings, when no grounds for issuing the order are found out (Article $498 \$ 2$ of the $\mathrm{CCP}^{33}$ ), or after effective opposition being raised against the order for payment (Article 505 of the $\mathrm{CCP}^{34}$ ), or after the order has been annulled ex officio (Article $502^{1}$ of the $\mathrm{CCP}^{35}$ ), it is not allowed to continue the process, using the rules of the European Small Claims Procedure. This possibility is precluded by the optional nature of this procedure and the absolute requirement to file the statement of claims on the appropriate official form. As a consequence, it is also not possible to proceed with the case in the European Small Claims Procedure.

A special regulation in this area is also included in Art. 4 subpara. 3 of the Regulation No. 861/2007, according to which, if the action brought does not cover cases in the scope of this Regulation, the court or tribunal informs the claimant thereof. If the claimant does not withdraw their claim, the court or tribunal shall proceed in accordance with the relevant procedural rules of the Member State in which the proceedings are

32 Order for payment is issued if the claimant pursues a pecuniary claim and in other cases, if the provisions stipulate so.

33 In the case, there are no reasons to issue an order for payment, the Presiding Judge schedules the hearing, unless the case may be examined in camera.

34 If the opposition against the order has been lodged correctly, the order for payment loses its force and the Presiding Judge assigns a deadline for the hearing and has the opposition together with the summons to the hearing served on the claimant. The order for payment loses its force in the part opposed against by the opposition. The opposition by only one of co-defendants for the same claim and as to only one or only some of claims taken into account, causes the loss of force of the order only as to them. At the defendant's request, the Court or the court assistant issues a decision at an in camera sitting, in which it ascertains that the order for payment has lost its force entirely or in part.

35 If the order for payment cannot be served for reasons indicated in Art. 499 point 4 of the CCP, the Court annuls the order for payment ex officio and the Presiding Judge undertakes relevant procedures. If after the issuance of the order for payment, it turns out that at the moment the statement of claims was brought into court, the defendant had no capacity to be a party to a court case, the process capacity or the body appointed to represent it and these failures have not been made good in the assigned deadline in accordance with the provisions of the Code, the Court annuls ex officio the order for payment and issues a relevant decision. The reasons for impossibility to serve the order for payment indicated in Art. 499 point 4 of the CCP are the lack of knowledge of the defendant's place of stay, or a case in which the service of the order cannot take place in Poland. 
conducted. This means that in such a case, the provisions dealing with the writ of payment proceedings may apply, of course, on condition that the case is eligible for examination in this mandatory procedure.

\subsection{ELECTRONIC WRIT OF PAYMENT PROCEEDINGS}

To determine cases that can be abstractly examined in both the European Small Claims Procedure and in electronic writ of payment proceedings, one shall be referred to Art. 2 and 3 of Regulation No. 861/2007 and Art. 505 ${ }^{28}$ in conjunction with Art. 498 $\$ 1$ of the CCP. These are civil and commercial cases of a cross-border nature, in which only pecuniary claims are pursued, provided that the value of the cause of action, interest, expenses and disbursements excluded, does not exceed the equivalent of EUR 5,000 at the moment the claim is brought to court, and in addition, these cases are not listed in Art. 2 subpara. 1 sentence 2 and subpara. 2 of the Regulation No. $861 / 2007$.

In order to show the relationship between the separate proceedings cited, it is of fundamental importance that both the European Small Claims Procedure and the electronic writ of payment proceedings are optional. On the grounds of the Polish Code of Civil Proceedings, if the claimant chooses the European Small Claims Procedure, then, these proceedings will be solely appropriate (compare Art. $505^{21} \$ 2^{36}$, Article $505^{27}$ $\$ 2^{37}$ and Article $505^{29} 38$ of the CCP).

The Polish legislator did not directly regulate the situation in which the claimant has chosen the electronic writ of payment proceedings, and while proceeding no grounds for issuing a payment order were found out (Article $505^{33} \S 1$ of the $\mathrm{CCP}^{39}$ ), or the court has ex officio annulled the order for payment (Article $505^{34} \S 1$ of the $\mathrm{CCP}^{40}$ ), or else an opposition against the order for payment has been successfully filed (Art. $505^{36}$ of the $\mathrm{CCP}^{41}$ ). It seems, however, that in the above situations, it is not allowed to apply subsequently the European Small Claims Procedure if only because of the optional nature of the proceedings and the absolute requirement to file the suit on the appropriate official form. ${ }^{42}$

36 Pursuant to Art. 50521 \$2 of the CCPin the case examined pursuant to the rules of the European Small Claims Procedure, no rules of other separate procedures are applied.

37 Reversing the judgement appealed against, issued in the European Small Claims Procedure, the second instance court transfers the case to be re-examined, the rules of separate procedures excluded.

38 In electronic writ of payment proceedings no rules of separate proceedings other than the writ of payment proceedings and the provisions of Art. 139 of the CCP are applied.

39 In the case, there are no bases to issue an order for payment, the court transfers the case to the court of the proper general competence.

40 In the case, the place of stay of the defendant is not known or the service of the order on them could not take place in Poland, the court annuls the order for payment ex officio and transfers the case to the court according to the general competence unless the claimant removes the obstacle in serving the order for payment on them in the deadline assigned.

41 In the case, when the opposition is lodged, the order for payment loses its force for its entirety and the court transfers the case to the court, according to the general competence. 


\subsection{SIMPLIFIED PROCEDURE}

Civil cases that can potentially be examined in both the proceedings indicated, are set out in Art. $505^{1}$ of the $\mathrm{CCP}^{43}$ and Art. 2 and 3 of the Regulation No. 861/2007. They are civil and commercial cases for claims, resulting from cross-border agreements, if the value of the object of the dispute or contract, interest, expenses and disbursements excluded, does not exceed the equivalent of EURO 5,000 and zloty 20,000 (or zloty 75,000 for claims from Art. $505^{1}$ point 2 of the $\mathrm{CCP}^{44}$ ) at the moment the claim is brought to court, and in addition these cases are not listed in Art. 2 subpara. 1 sentence 2 and subpara. 2 of the Regulation No. 861/2007.

If the claimant chooses the optional European Small Claims Procedure, it becomes exclusively competent to examine the given case, thus, in accordance with Art. $505^{21} \$ 2$ of the CCP, in the light of which, in the case examined under the provisions of the European Small Claims Procedure, the rules of other separate proceedings do not apply. The rule contained in Art. $505^{27} \$ 1$ of the CCP is not contradictory to the above. It stipulates that in the European Small Claims Procedure, in the proceedings before the second instance court, several provisions of the simplified procedure indicated by the legislator apply, i.e. Art. $505^{9}-505^{11}$, Art. $505^{12} \S 1$ and 3 and Art. $505^{13}$ of the CCP. Bearing in mind sped up and simplified nature of the European Small Claims Procedure, the legislator considered it rational to simplify also the appellate proceedings, whereby these proceedings were constructed in a way similar to the appellate procedure in simplified proceedings, and in consequence, it became sufficient to refer to the provisions which regulate simplified proceedings and are listed by the legislator.

As argued earlier, in the European small claims procedure, at the stage of appellate proceedings, the following rules of simplified procedure are applied:

1) Art. 5059 of the CCP - setting out types of arguments, on which the appeal can be based and excluding further pleas that must not be raised after the deadline to submit the appeal;

2) Art. 50510 of the CCP - one-person panel of the Court, judging the appeal, the right to examine the appeal in camera, if in the appeal or the reply to the appeal, the oral trial hearing was not requested;

3) Art. 50511 of the CCP - restriction of the evidence taking to documents with the exception of the case, when the appeal was based on later revealed factual circumstances or evidence which the party was not able to take advantage of in the first instance court;

43 The rules of simplified proceedings are applied in the following cases, belonging to the competence of the district courts:

1) claims, arising from the contracts, if the value of cause of action does not exceed twenty thousand zloty and in cases for a claim, arising from quality guarantee, warranty or from the incompliance of the thing sold to the consumer with the contract, if the value of the object of the contract does not exceed this amount of money;

2) for the payment of rents for tenancy of flats/houses and fees charging the tenants and fees, arising from the use of a flat in a housing cooperative notwithstanding the value of the object of dispute.

44 Cases for property rights in which the value of the object of dispute goes beyond an amount of seventy five thousand zloty apart from cases for maintenance, infringement of possession, for establishing matrimonial separated properties between the spouses, for reconciliation of the land and mortgage register content with the actual legal status and cases examined in the electronic writ of payment proceedings which belong to the competence in materia of the general court as the court of the first instance (Art. 17 point. 4 of the CCP). 
4) Art. $50512 \S 1$ of the CCP - reversing of the judgment under appeal, if a breach of substantive law is found out, if the evidence gathered does not provide sufficient grounds for a change of the judgment;

5) Art. $50512 \$ 3$ of the CCP - dismissal of the appeal if, despite a breach of substantive law or procedural provisions or else incorrect justification, the judgment appealed against complies with the law;

6) Art. 50513 of the CCP - limiting the justification of the judgment to the clarification of the legal basis with legal provisions cited in a situation when the court of the second instance did not conduct evidential proceedings.

After the reversal of the judgment by the court of the second instance, if any, the exclusivity of the European Small Claims Procedure is replaced by the exclusivity of ordinary procedure within the hearing mode in accordance with the disposition of Art. $505^{27} \$ 2$ of the CCP.$^{45}$ Further proceedings will, therefore, be under way, overriding the provisions of all separate proceedings, those of the European Small Claims Procedure included. It shall be emphasized that the exclusion of the admissibility of the European Small Claims Procedure in this situation is justified, since it was in this procedure that a ruling was issued which was effectively overruled in proceedings by the second instance court and thus, the case must not be re-examined in the manner provided for in the Regulation No. 861/2007.

Of course, the special regulation contained in Art. 4 subpara. 3 of the Regulation No. $861 / 2007$ shall be borne in mind, pursuant to which the court or tribunal informs the claimant if the action does not concern matters falling within the scope of this regulation. If the claimant does not withdraw his claims, the court or tribunal shall proceed in accordance with the relevant procedural rules of the Member State in which the proceedings are conducted. This means that in such a case the provisions, regulating the simplified proceedings may be applicable, provided, of course, that the case is eligible to be examined in this mandatory procedure.

\subsection{EUROPEAN ORDER FOR PAYMENT PROCEDURE}

Matters that are theoretically common for both listed proceedings shall be set out on the basis of Art. $505^{15} \$ 1$ of the CCP in conjunction with Art. 2, 3 and 4 of the Regulation (EC) No. 1896/2006 of the European Parliament and of the Council of 12 December $2006^{46}$ (as amended by the Regulation 2015/2421 previously cited) which established

$45 \quad$ Reversing the judgement appealed against, the second instance court will transfer the case to be reexamined with the exclusion of the provisions on separate proceedings.

46 The Official Journal of the European Union L 399 of 30 December 2006, p.1, hereinafter referred to as the Regulation No. 1896/2006. Pursuant to Art. 2 to this Regulation, it is applied to cross-border civil and commercial matters notwithstanding the type of court or tribunal. It is not applicable in particular to revenue customs and administrative matters or the liability of the State for acts and omissions in the exercise of the State authority (acta iure imperii), rights in property, arising from matrimonial relationships, wills and succession, bankruptcy, proceedings related to winding up insolvent companies or other legal persons, judicial arrangements, compositions and other analogous proceedings, social insurance, claims arising from non-contractual obligations unless they are the subject of an agreement between the parties and the debt has been acknowledged or they refer to debts denominated and arising from the co-ownership of the property. Art. 3 of the Regulation No. 1896/2006 stipulates that the crossborder case shall be understood as that in which at least one of the parties is domicile or habitually resident in a Member State other than the Member State of the court which examines the case and the cross-border case shall be evaluated, according to the status of the day when the claim for the issuance 
the European order for payment and Article $505^{21} \$ 1$ of the CCP in conjunction with Art. 2 and 3 of the Regulation No. 861/2007. Thus, this relates to cross-border civil and commercial cases which refer to pecuniary claims that are due at the time the action is brought, on condition that the value of the cause of action, interest, expenses and disbursements excluded, does not exceed the equivalent of EUR 5,000 at the time the court is seized, and furthermore, no exemptions included in the cited provisions are to be taken into account.

The relationship between these proceedings was determined by the Polish legislator very precisely. In the case, when the claimant chooses the European Small Claims Procedure, the exclusivity of these proceedings results directly from Art. $505^{21} \$ 2$ and Art. 505 ${ }^{27}$ $\$ 2$ of the CCP. However, if the claimant chooses the European order for payment procedure, then, this procedure is the only appropriate, as in accordance with Art. 505 ${ }^{15}$ $\$ 2$ of the CCP in the case examined under the provisions of the European order for payment procedure, the provisions of other separate proceedings are not applied.

And yet, two special situations shall be underlined for their unique regulation.

In the case, when the claimant agrees for a European order for payment to be issued only for a part of the claim (Article $505^{18} \$ 1$ of the Code of Civil Proceedings), the court will hear the case which regards the rest of the claim in the appropriate mode, and in the cases specified in the Act, according to the rules on separate proceedings. However, the order for payment and the writ of payment proceedings are excluded for a part of the claims for which the European order for payment could not have been issued. It raises no doubts that the use of the term 'mode' by the Polish legislator may suggest that in such a case the court may also refer the case to non-litigious proceedings. However, bearing in mind the fact that the Regulation No. 1896/2006 does not apply to revenue, customs or administrative matters, nor to those which regard State liability for acting and omission to act in the exercise of State authority (acta iure imperii), property rights, arising from marital relations, wills and inheritance, bankruptcy, proceedings related to the liquidation of insolvent companies or other legal persons, conciliation proceedings, arrangements and other analogous proceedings, social security, claims arising from non-contractual obligations, unless they are the subject of an agreement between the parties or the debt has been recognized, or concern denominated debts arising from joint ownership of property (Article 2 subpara. 2 and 3), this needs to assume that such a procedural situation must not be considered as possible in practice. ${ }^{47}$ As to the examination of the case with the application of the provisions on mandatory simplified proceedings, if any, a major obstacle to such a solution is the requirement to submit the claim in simplified proceedings on the appropriate official form. In turn, the source of exclusion of the admissibility of the order of payment and the writ of payment proceedings is the fact that as the European order of payment procedure is an alternative to the domestic order of payment and writ of payment proceedings then, in

of the European order of payment was submitted in accordance with this Regulation. In accordance with Art. 4 of the above cited Regulation, the European order for payment procedure will be established to collect pecuniary claims for a specific amount of money which has fallen due on the day when the application for a European order for payment is submitted.

47 It seems that in the present legal environment, the application of the word 'mode' used in. $505^{19} \$ 1$ CCP shall be replaced at least by the notion of 'civil proceedings', compare Art. 17 of the Regulation No. $1896 / 2006$. 
the situation in which the court may not issue a European order for payment, the same needs to apply to the issuance of an order in the writ of payment proceedings, and not to allow the reuse of another sped up separate proceedings. ${ }^{48}$ It also needs emphasizing that it results from the essence and the nature of the analyzed proceedings in which the legislator excluded the right to examine the case in the writ of payment proceedings, that the claimant's claim must not be pursued either in the ordinary writ of payment proceedings nor in the electronic writ of payment proceedings. As an additional comment, it can be argued that this seems to be obvious in view of the optional nature of this procedure, in consequence of which its pursuance depends on the will of the claimant, not of the court.

In the light of the above, there is no doubt that the case may be examined in ordinary procedural proceedings.

On the other hand, when an opposition is effectively raised against the European order for payment, the order loses its force (Article $505^{19} \$ 1$ of the CCP) and further proceedings will take place before the competent courts in the Member State of origin, unless the claimant has explicitly requested the proceedings be terminated (Art. 17 subpara. 1 sentence 1 of the Regulation No. 1896/2006). ${ }^{49}$

Further proceedings, if any, will be carried out in accordance with the rules:

(a) of the European Small Claims Procedure in accordance with the Regulation No. 861/2007, if applicable;

or

(b) the applicable national civil procedural law (Art. 17 subpara. 1 sentence 2 of the Regulation 1896/2006).

However, if the claimant does not indicate which of the abovementioned proceedings are to be applied to examine their claim in the proceedings to be taken as a result of the opposition or when the claimant requested the European Small Claims Procedure be applied under the Regulation No. 861/2007 and their claim is not included in the scope of the Regulation, the case will be referred to the relevant national civil procedure, unless the claimant has explicitly requested that no such a transfer be made (Article 17 subpara. 2 of the Regulation 1896/2006).

The referral of the case to the European Small Claims Procedure or to any other civil proceedings appropriate under national law is subject to the law of the issuing Member State, that is the national law of that Member State (Article 17 subpara. 4 of the

$48 \quad$ K Weitz, in T Ereciński (ed), Kodeks postępowania cywilnego. Komentarz. Postępowanie rozpoznawcze. (Commentary. Fact-finding procedure), V. II (LexisNexis 2012) 982, compare also the justification of the bill related to the change of the law, the Code of Civil Proceedings and some other laws, The Seym print no 949 office VI, 41-42.

49 Pursuant to the judgement of CJEU of 13 June 2013 in case C-144/12 Goldbet Sportwetten GmbH v Massimo Sperindeo <http://curia.europa.eu/> accessed 2 May 2019 it cannot be claimed that the proceedings of the European order for payment and the national civil proceedings pending upon its completion are in reality one and the same procedure. Such an interpretation would be difficult to agree with the circumstance that the first of these proceedings is conducted pursuant to the rules of the Regulation No. 1896/2006, while the other, which results from Art. 17 subpara. 1 of the Regulation is conducted pursuant to the provisions of the national civil proceedings. In consequence, submitting an opposition against a European order ends formally the procedure for the issuance of the European order for payment, and therefore, this procedure and that following it, the national civil procedure make up formally separate proceedings. 
Regulation 1896/2006). At the same time, it shall be emphasized that in consequence of the amendment to the Regulation No. 1896/2006 already cited, the provision of Art. 17 of the Regulation does not currently use the term 'ordinary civil proceedings', because it was replaced by 'national civil procedure'.

By regulating the transition to the national law in the event of an effective opposition against a European order for payment, the Polish Code of Civil Proceedings also stipulates that in such a case, the court examines the case in the appropriate mode, and in the cases indicated in the Act, in accordance with the provisions on separate proceedings, however, the order for payment and the writ of payment proceedings excluded (Article $505^{19} \$ 1$ of the CCP), whereby the earlier comments with regard to the case referral by the court to non-litigious proceedings, optional electronic writ of payment proceedings along with simplified proceedings also apply to this case.

And yet, in the indicated situation, the case may be without doubt examined in a new, formally separate procedure ${ }^{50}$ that will be conducted by the court in ordinary civil trial proceedings.

\section{CONCLUDING REMARKS}

To sum up all the considerations, it is worth recalling the basic theses of the findings arrived at:

1) the European Small Claims Procedure is an alternative to the existing procedures under the laws of the Member States;

2) this procedure is optional, because the claimant decides whether they will use the procedure, by expressing their will when they file the lawsuit on a special form;

3) the European Small Claims Procedure can be included into simplified and sped up proceedings, since the course of this procedure, and in particular the possibility of examining the case in camera, indicates features common with this group of separate proceedings;

4) the feature of the European Small Claims Procedure, distinguishing it from other separate proceedings (with the exception of the European order for payment procedure) is the cross-border nature of the case;

5) if the claimant chooses the European small claims procedure, then, these proceedings will be the only appropriate ones;

6) there is a prohibition in the Code of Civil Proceedings to combine the European Small Claims Procedure with the order for payment proceedings, which refers to proceedings before the courts of both instances;

7) if the claimant chooses the European Small Claims Procedure for their claims, the referral of the case to the ordinary writ of payment proceedings is excluded;

8) in the case, the claim is pursued in the writ of payment proceedings, when no grounds for issuing the order for payment are established, or after an effective opposition against the order for payment is filed or after the order for payment is annulled ex officio, it is not allowed to continue the process based on the provisions of the European Small Claims Procedure;

9) if the claimant chooses the electronic writ of payment proceedings, and in their course no grounds for issuing the order for payment are established, or the order for

$\overline{50 \quad \text { Compare (n 47). }}$ 
payment is annulled ex officio or an effective opposition against the order for payment is filed, the use of the European Small Claims Procedure is not allowed;

10) if the claimant has chosen the European order for payment, then, this procedure is the only appropriate;

11) pursuant to Art. 4 subpara. 3 of the Regulation No. 861/2007, if the action brought does not refer to matters covered by the scope of this Regulation, the court or tribunal informs the claimant thereof. If the claimant does not withdraw their claim, the court or tribunal shall proceed in accordance with the relevant procedural rules of the Member State in which the proceedings are conducted. This means that in such a case, the provisions, which deal with the mandatory writ of payment or simplified proceedings may be applied, provided, of course, the case is eligible for the examination in such proceedings;

12) the rules of the European Small Claims Procedure clearly indicate that the proceedings are autonomous when compared to other separate proceedings. 